\title{
Chinese Medicines Induce Cell Death: The Molecular and Cellular Mechanisms for Cancer Therapy
}

\author{
Xuanbin Wang, ${ }^{1,2}$ Yibin Feng, ${ }^{1}$ Ning Wang, ${ }^{1}$ Fan Cheung, ${ }^{1}$ Hor Yue Tan, \\ Sen Zhong, ${ }^{2}$ Charlie $\mathrm{Li}^{3}{ }^{3}$ and Seiichi Kobayashi ${ }^{4}$ \\ ${ }^{1}$ School of Chinese Medicine, The University of Hong Kong, 10 Sassoon Road, Pokfulam, Hong Kong \\ ${ }^{2}$ Laboratory of Chinese Herbal Pharmacology, Hubei Key Laboratory of Wudang Local Chinese Medicine Research, School of Pharmacy, \\ Hubei University of Medicine, Shiyan, Hubei 442000, China \\ ${ }^{3}$ California Department of Public Health, 850 Marina Bay Parkway, G365, Richmond, CA 94804, USA \\ ${ }^{4}$ Faculty of Healthy Science, Hokkaido University, Kita 15, Nishi 7 Kita-ku, Sapporo, Japan
}

Correspondence should be addressed to Yibin Feng; yfeng@hku.hk

Received 24 May 2014; Accepted 23 July 2014; Published 14 October 2014

Academic Editor: Gagan Deep

Copyright (C) 2014 Xuanbin Wang et al. This is an open access article distributed under the Creative Commons Attribution License, which permits unrestricted use, distribution, and reproduction in any medium, provided the original work is properly cited.

Chinese medicines have long history in treating cancer. With the growing scientific evidence of biomedical researches and clinical trials in cancer therapy, they are increasingly accepted as a complementary and alternative treatment. One of the mechanisms is to induce cancer cell death. Aim. To comprehensively review the publications concerning cancer cell death induced by Chinese medicines in recent years and provide insights on anticancer drug discovery from Chinese medicines. Materials and Methods. Chinese medicines (including Chinese medicinal herbs, animal parts, and minerals) were used in the study. The key words including "cancer", "cell death", "apoptosis", "autophagy," "necrosis," and "Chinese medicine" were used in retrieval of related information from PubMed and other databases. Results. The cell death induced by Chinese medicines is described as apoptotic, autophagic, or necrotic cell death and other types with an emphasis on their mechanisms of anticancer action. The relationship among different types of cell death induced by Chinese medicines is critically reviewed and discussed. Conclusions. This review summarizes that CMs treatment could induce multiple pathways leading to cancer cell death, in which apoptosis is the dominant type. To apply these preclinical researches to clinic application will be a key issue in the future.

\section{Introduction}

Cancer is one of the leading causes of death in the world. GLOBOCAN data revealed that approximately 12.7 million new cases of cancers have been diagnosed and 7.6 million deaths were attributed to cancers in 2008 [1]. In these lifethreatening cancers, the causes are diverse and complex and are only partially understood; the reasons why they are difficult to cure might be due to the complicated cancer hallmarks: sustaining proliferative signaling, resisting cell death, inducing angiogenesis, enabling replicative immortality, activating invasion and metastasis, evading growth suppressors, irregulating cellular energetic, genome instability, and mutation as well as tumor-promoting inflammation, and avoiding immune destruction, among which resisting cell death is the intracellular or external factors-triggered tumor action to escape from insult [2].

Cell death has conventionally been divided into three types: apoptosis (Type I), autophagy (Type II), and necrosis (Type III) [3, 4]. Apoptosis, Type I programmed cell death (PCD), is a normal response of a physiological process; it becomes a pathological trait in many diseases including cancers when apoptosis is irregulated. It is also the major type of cell death induced by most of the frontline chemotherapeutic agents $[3,5,6]$. In the process of apoptotic cell death, cells have altered morphology such as blebbing, cell shrinkage, nuclear fragmentation, and chromatin condensation. Morphological features of Type II cell death are different from those of apoptosis, in which formation of autophagosome and cytolysis of autophagosome-lysosome 
fusion involve the degradation of the components in cancer cells through the lysosomal machinery [7]. Type III cell death is a necrotic process whose typical characteristics of necrosis include disruption of plasma membrane and induction of inflammation that have been conventionally regarded as an accidental, uncontrolled cell death. However, recent studies found that necrosis could be under control as it shared the same stimuli (cytokines, pathogens, ischemia, heat, and irradiation), signaling pathways (death receptors, kinase cascades, and mitochondrial), and protective mechanisms (Bcl$2 / \mathrm{Bcl}-\mathrm{x}$, heat shock protein) as apoptosis $[5,8]$. Besides these three types of cell death, several other cell death pathways have been elucidated [4, 9-12]. Since these distinct cell deaths have different subroutines, the Nomenclature Committee on Cell Death (NCCD) has proposed a set of recommendations to define cell deaths based on the biochemical and functional condensation in 2012 [9].

Since many of the clinical anticancer drugs are originally from natural sources, such as vinca alkaloids and taxanes, up to date, some studies have focused on the herbal medicinal products, especially Chinese medicines (CMs, including plants, animals, and minerals) [13-18]. Natural products are important sources of anticancer lead molecules. Many successful anticancer drugs come from natural products. More are still under clinical trials. The aim is to develop novel anticancer drugs derived from natural products, especially from CMs. More critical systematic studies on cellular and molecular therapeutic principle of anticancer natural products from CMs in cancer cell deaths need to be conducted.

In this review, we retrieved the relevant publications from PubMed and other databases to summarize the actions of CMs involved in inducing cancer cell death in vitro and in vivo. Besides clinical applications, other novel cell death pathways and the relevance of CMs in these fields are also discussed here.

\section{CMs Induce Cancer Cell Death and Their Underlying Mechanisms}

2.1. CMs Induce Apoptotic Death in Human Cancer Cells. Both intrinsic and extrinsic pathways involve activation of apoptosis by CMs in human cancer cells. The CM-initiated apoptotic cell death is mainly dependent on the activation of caspase cascade. There are two types of apoptotic caspases: initiator (apical) caspases and effector (executioner) caspases. Initiator caspases (e.g., CASP2, CASP8, CASP9, and CASP10) cleave inactive proforms of effector caspases, thereby activating them. Initially, caspases are cysteine-aspartic proteases or cysteine-dependent aspartate-directed proteases in inactive forms. They are cleaved by interacting special molecules such as Apaf-1 (apoptotic protease-activating factor-1), Fas/CD95, or tumor necrosis factor $\alpha(\mathrm{TNF} \alpha)$ when apoptosis is induced in cells $[9,132]$. Extrinsic apoptosis depends on caspase activation, while intrinsic apoptosis is either in caspasedependent or -independent manner $[9,133]$. CMs can activate cancer cell death extrinsically, intrinsically, or both; therefore the mechanisms of CMs inducing cancer apoptotic cell death have been more diversified. Table 1 summarizes the general information of CMs inducing apoptotic cell death. The typical examples are in Table 1 and Figure 1.

2.1.1. CMs Induce Apoptosis Intrinsically. CMs-induced intrinsic apoptosis mainly requires the activation of caspases. CMs can also induce apoptotic cell death by caspaseindependent manner because some types of cancer cells can ablate the expression of caspases. In addition, even in caspase-proficient cancer cells, CMs treatment can activate all types of intrinsic apoptosis, eventually leading to potent cancer cell death.

Ursolic acid (UA) is an active ingredient in several CMs, such as Oldenlandia diffusa (Willd.) Roxb. (Chinese name: Baihuasheshecao), Ligustrum lucidum W.T.Aiton (Chinese name: Nuzhen), and Eriobotrya japonica (Thunb.) Lindl. (Chinese name: Pipa). Previous studies showed that UA could induce cancer cell death by enabling the caspasedependent pathway. It was reported that UA activated caspase- 3 and caspase- 9 in human prostate cancer cells, $\mathrm{RC}-58 \mathrm{~T} / \mathrm{h} / \mathrm{SA} \# 4$ [32]. UA binding with oleanolic acid could elevate the caspase-3 activity in human liver cancer cells, Huh7, HepG2, Hep3B, and HA22T [35]. Its antitumor effect was also observed in xenograft model. The results of positron-emission tomography-computed tomography (PET-CT) imaging indicated that proliferation of tumor cells declined after UA treatment in vivo $[34,134]$. Generally, the mechanism of CMs to cause intrinsic cell death in cancer is caspase-dependent. CMs induced the release of cytochrome $c$ from mitochondria [23], which facilitated the activation of apoptotic protease-activating factor-1 (Apaf-1) and forms Apaf-1 apoptosome that bound to caspase- 9 through CARDCARD (caspase recruitment domain) interactions to form a holoenzyme complex $[135,136]$. The complex cleaved caspase- 3 to produce a caspase cascade resulting in cell death $[94,136]$. The mechanisms of some representative CMs inducing cancer intrinsic cell death are illustrated in Figure 1.

Apart from caspase-dependent cell death, CMs could initiate apoptosis in both caspase-dependent and caspaseindependent manners. The main biochemical pathway of caspase-independent cell apoptosis was elucidated as the results of release of mitochondrial intermembrane space (IMS) proteins and inhibition of respiratory chain. In this context, apoptosis-inducing factor (AIF) and endonuclease $G$ (Endo $G$ ) relocated to the nucleus and mediate largescale DNA fragmentation. The serine protease, a high temperature requirement protein A2 (HTRA2), cleaved many cellular substrates including cytoskeletal proteins as well [9]. Gypenosides (Gyp), derived from Gynostemma pentaphyllum (Thunb.) Makino (Chinese name: Jiaogulan), could suppress the growth of WEHI-3 cells in vitro and in vivo through caspase-dependent and -independent apoptosis. Gyp inhibited Bcl-2, increased Bax, and induced the release of cytochrome $c$ and depolarization of mitochondrial membrane potential $(\Delta \psi)$ and stimulated the activities of caspase3 and caspase-8, suggesting that Gyp triggered caspasedependent cell death. Gyp also induced the generation of ROS and stimulated the release of AIF and Endo G, 
TABLE 1: Pure compounds and fractions of CMs inducing cancer cell death and the pathways.

\begin{tabular}{|c|c|c|}
\hline Compounds & Resource/Chinese name & Cell death pathway \\
\hline Artemisinins & Artemisia annua L./qinghao & Apoptosis, necrosis [19-21]. \\
\hline $\begin{array}{l}\text { Tanshinone IIA; } \\
\text { cryptotanshinone }\end{array}$ & Salvia miltiorrhiza Bunge/Danshen & $\begin{array}{l}\text { Tanshinone IIA: apoptosis } \\
{[22,23] \text {; autophagy [24]; }} \\
\text { cryptotanshinone: apoptosis [25] }\end{array}$ \\
\hline Pseudolaric acid B & Pseudolarix kaempferi Gordon/Jinqiansong & $\begin{array}{l}\text { Autophagy [26]; apoptosis } \\
{[27,28]}\end{array}$ \\
\hline Ursolic acid & $\begin{array}{l}\text { Oldenlandia diffusa (Willd.) Roxb./Baihuasheshecao; } \\
\text { Ligustrum lucidum W.T.Aiton/Nüzhen; Eriobotrya } \\
\text { japonica (Thunb.) Lindl./Pipa }\end{array}$ & $\begin{array}{l}\text { Autophagy }[29,30] \text {; apoptosis } \\
{[31-35]}\end{array}$ \\
\hline Triptolide & Tripterygium wilfordii Hook. f./Leigongteng & $\begin{array}{l}\text { Both apoptosis and autophagy } \\
\text { [36]; autophagy [37]; apoptosis } \\
\text { [38] }\end{array}$ \\
\hline Oridonin & Rabdosia rubescens (Hemsl.) Hara/Donglingcao & $\begin{array}{l}\text { Autophagy }[39,40] \text {; both } \\
\text { autophagy and apoptosis } \\
{[39,41,42] \text {; apoptosis }[43,44]}\end{array}$ \\
\hline $\begin{array}{l}\beta \text {-Elemene; } \\
\text { curcumol }\end{array}$ & Curcuma wenyujin Y.H.Chen and C.Ling/Ezhu & $\begin{array}{l}\beta \text {-Elemene: apoptosis [45-49] } \\
\text { Curcumol: apoptosis [50] }\end{array}$ \\
\hline $\begin{array}{l}\text { Rp1, Rg3, Rh2, Rk1, Rg5, } \\
\text { etc. }\end{array}$ & Panax ginseng C.A.Mey./Renshen & $\begin{array}{l}\text { Extracts: apoptosis [51-55]; } \\
\text { Rg3: apoptosis (via decrease of } \\
\text { Pim-3 and pBad; NF- } \kappa \text { B } \\
\text { inactivation) [56, 57]; } \\
\text { Rh2: apoptosis and } \\
\text { paraptosis-like cell death } \\
\text { [42, 58, 59]; apoptosis [60]; } \\
\text { Rp1: paraptosis [61]; apoptosis } \\
\text { [62]; } \\
\text { KG-135 with etoposide (formula } \\
\text { of Rk1, } \operatorname{Rg} 3 \text { and } \operatorname{Rg} 5 \text { ): apoptosis } \\
\text { [63] }\end{array}$ \\
\hline Polyphyllin D & Paris polyphylla Sm./Chong Lou & Apoptosis $[64,65]$ \\
\hline Gypenosides & $\begin{array}{l}\text { Gynostemma pentaphyllum (Thunb.) } \\
\text { Makino/Jiaogulan }\end{array}$ & Apoptosis $[66]$ \\
\hline $\begin{array}{l}\text { Baicalin; wogonin; } \\
\text { oroxylin A; baicalein }\end{array}$ & Scutellaria baicalensis Georgi./Huangqin & Apoptosis $[67-75]$ \\
\hline Hesperidin & Citrus reticulate Blanco./Chenpi & Apoptosis [76-78] \\
\hline $\begin{array}{l}\text { Glycyrrhizin; } \\
18 \beta \text {-glycyrrhetinic acid }\end{array}$ & Glycyrrhiza glabra L./Gancao & Apoptosis [79-81] \\
\hline Eugenol & Areca catechu L./Binlang & Apoptosis [82] \\
\hline $\begin{array}{l}1^{\prime} S-1^{\prime} \text {-acetoxyeugenol } \\
\text { acetate }\end{array}$ & Alpinia conchigera Griff./Jiebianshanjiang & $\begin{array}{l}\text { Apoptosis (via NF- } \kappa \mathrm{B} \\
\text { inactivation) }[83]\end{array}$ \\
\hline $\begin{array}{l}\text { Catechins } \\
\text { (-(epicatechin-3-gallate } \\
(\text { EGCG)), polyphenols }\end{array}$ & Camellia sinensis (L.) Kuntze/Cha & $\begin{array}{l}\text { EGCG: autophagy } \\
{[42,58,59,84] ; \text { apoptosis }} \\
{[74,75] ; \text { anoikis [85]; parthanatos }} \\
{[86] ;} \\
\text { catechin: apoptosis [87]; } \\
\text { polyphenols (GrTP): apoptosis } \\
{[88-90]}\end{array}$ \\
\hline Cryptocaryone & Cryptocarya concinna Hance/Tunan & Apoptosis [91] \\
\hline Curcumin & Curcuma longa L./Jianghuang & Apoptosis $[92,93]$ \\
\hline Emodin & Rheum palmatum L./Dahuang & Apoptosis $[45-48,94]$. \\
\hline Aloe emodin & $\begin{array}{l}\text { Rheum palmatum L./Dahuang; } \\
\text { Polygonum cuspidatum Siebold \& Zucc./Huzhang }\end{array}$ & Apoptosis $[95,96]$ \\
\hline Silibinin & Silybum marianum (L.) Gaertn./Shuifeiji & $\begin{array}{l}\text { Apoptosis }[97-100] \\
\text { autophagy }[46,101]\end{array}$ \\
\hline
\end{tabular}


TABLe 1: Continued.

\begin{tabular}{|c|c|c|}
\hline Compounds & Resource/Chinese name & Cell death pathway \\
\hline Gambogic acid & Garcinia hamburgy Hook. f./Tenghuang & Apoptosis [102-104] \\
\hline Shikonin & Lithospermum erythrorhizon Siebold \& Zucc./Zicao & $\begin{array}{l}\text { Apoptosis [105]; } \\
\text { necroptosis [106, 107] }\end{array}$ \\
\hline Berberine & Coptischinensis Franch/Huanglian & $\begin{array}{l}\text { Apoptosis }[108,109] ; \\
\text { autophagy }[110,111] \text {; necrosis } \\
\text { [112]; anoikis [113] }\end{array}$ \\
\hline Camptothecin & Camptotheca acuminate Decne./Xishu & Apoptosis [114] \\
\hline $\begin{array}{l}\text { Tetrandrine; } \\
\text { fangchinoline }\end{array}$ & Stephania tetrandra S. Moore/Fangji & $\begin{array}{l}\text { Tetrandrine: apoptosis }[50,115] \text {; } \\
\text { fangchinoline: autophagy [34] }\end{array}$ \\
\hline $\begin{array}{l}\text { Matrine; } \\
\text { oxymatrine }\end{array}$ & Sophora flavescens Ait./Kushen & $\begin{array}{l}\text { Matrine: apoptosis }[116,117] \\
\text { autophagy [118-120]; } \\
\text { oxymatrine: apoptosis [121] }\end{array}$ \\
\hline Herbal extracts & Zanthoxylum ailanthoides Siebold \& Zucc./Shizhuyu & Apoptosis [122] \\
\hline Pharicin A & Isodon amethystoides (Benth.) H. Hara,/Xiangchacai & Mitotic catastrophe [123] \\
\hline Casticin & Vitex rotundifolia L.f./Manjing & $\begin{array}{l}\text { Mitotic catastrophe and } \\
\text { apoptosis [124] }\end{array}$ \\
\hline $\begin{array}{l}\text { Selenium-rich amino } \\
\text { acids }\end{array}$ & silkworm pupas/Chanyong & Apoptosis [125] \\
\hline Arsenic trioxide & Pishuang & $\begin{array}{l}\text { Necrosis [126]; apoptosis } \\
{[45-48,127-130] ;} \\
\text { autophagy [131] }\end{array}$ \\
\hline
\end{tabular}

resulting in caspase-independent cell death [66]. Silibinin (from Shuifeiji, silybum marinaum (L) Gaenrt) was reported to stimulate the release of HTRA2 and AIF in bladder carcinoma cell line 5637 as well as cytochrome $c$ and activate caspase-3. Thus silibinin could induce bladder cell death in both caspase-dependent and -independent manners [100] (Figure 1, Table 1).

There are some relationships between CMs and intrinsic death stimuli, for example, Scutellaria, one of the most popular CM herbal remedies, used in China and several oriental countries for treatment of inflammation, bacterial, and viral infections, and it has been shown to possess anticancer activities in vitro and in vivo in mouse tumor models [137, 138]. The bioactive components of Scutellaria were confirmed to be flavonoids [138, 139]. Chrysin is a natural flavone commonly found in honey that has been shown to be an antioxidant and anticancer agent [140]. Several studies showed that Chrysin and Apigenin could potentiate the cytotoxicity of anticancer drugs by depleting cellular GSH, an important factor in antioxidant defense [141143]. A 50-70\% depletion of intracellular GSH was observed in prostate cancer PC-3 cells after $24 \mathrm{~h}$ of exposure to $25 \mu \mathrm{M}$ Chrysin or Apigenin [141, 144].

2.1.2. CMs Induce Apoptosis Extrinsically. Since extrinsic apoptosis of cancer cells is initiated by binding of death receptors and their ligands, the death receptors may function as signaling gateway in which Fas/CD95 ligands (FasL/CD95L) and some cytokines such as $\mathrm{TNF} \alpha$ and TNF superfamily member 10 (TNFSF10, also known as TRAIL) play great roles in inducing apoptosis. These lethal cytokines activate Fas-associated protein with a "death domain" (FADD) and thereby activate caspase- $8 / 10$, caspase- 3 , caspase- $6 / 7$ to a cascade apoptosis response. Matrine, an alkaloid purified from Sophora flavescens Ait. (Chinese name: Kushen), induces the apoptosis of gastric carcinoma cells SGC-7901. A study using MTT assay showed that matrine inhibited SGC-7901 cells proliferation in dose- and time-dependent manners. Furthermore, the levels of both Fas and FasL were found to be upregulated after matrine treatment, which resulted in apoptotic cell death by the activation of caspase-3 [116]. Other CMs involved in the induction of extrinsic apoptosis included oridonin (from Donglingcao, Rabdosia rubescens (Hemsl.) Hara) [44], polyphenols from green tea [88, 89], and glycyrrhizin (from gancao, Glycyrrhiza glabra L.) [81], as listed in Table 1.

2.1.3. CMs Induce Both Intrinsic and Extrinsic Apoptosis. Some of CMs exhibit a complex nature by inducing both intrinsic and extrinsic apoptosis. Kim et al. found that UA induced the expression of Fas and cleavage of caspase- 3 and caspase- 8 as well as caspase- 9 and decreased its $\Delta \psi$. Other effects, such as Bax upregulation, Bcl-2 downregulation, and the release of cytochrome $c$ to the cytosol from mitochondria, were caused by UA treatment [31] (Figure 1, Table 1).

2.2. CMs Induce Autophagic Cancer Cell Death. Autophagic cell death is characterized with a massive cytoplasmic vacuolization resulting in physiological cell death, which is particularly induced when cells are deficient in essential apoptotic modulators such as Bcl-2 family and caspases. Some of the CMs induce autophagy via several signaling pathways that mediates the downregulation of mammalian target of rapamycin (mTOR) and upregulation of Beclin-1 


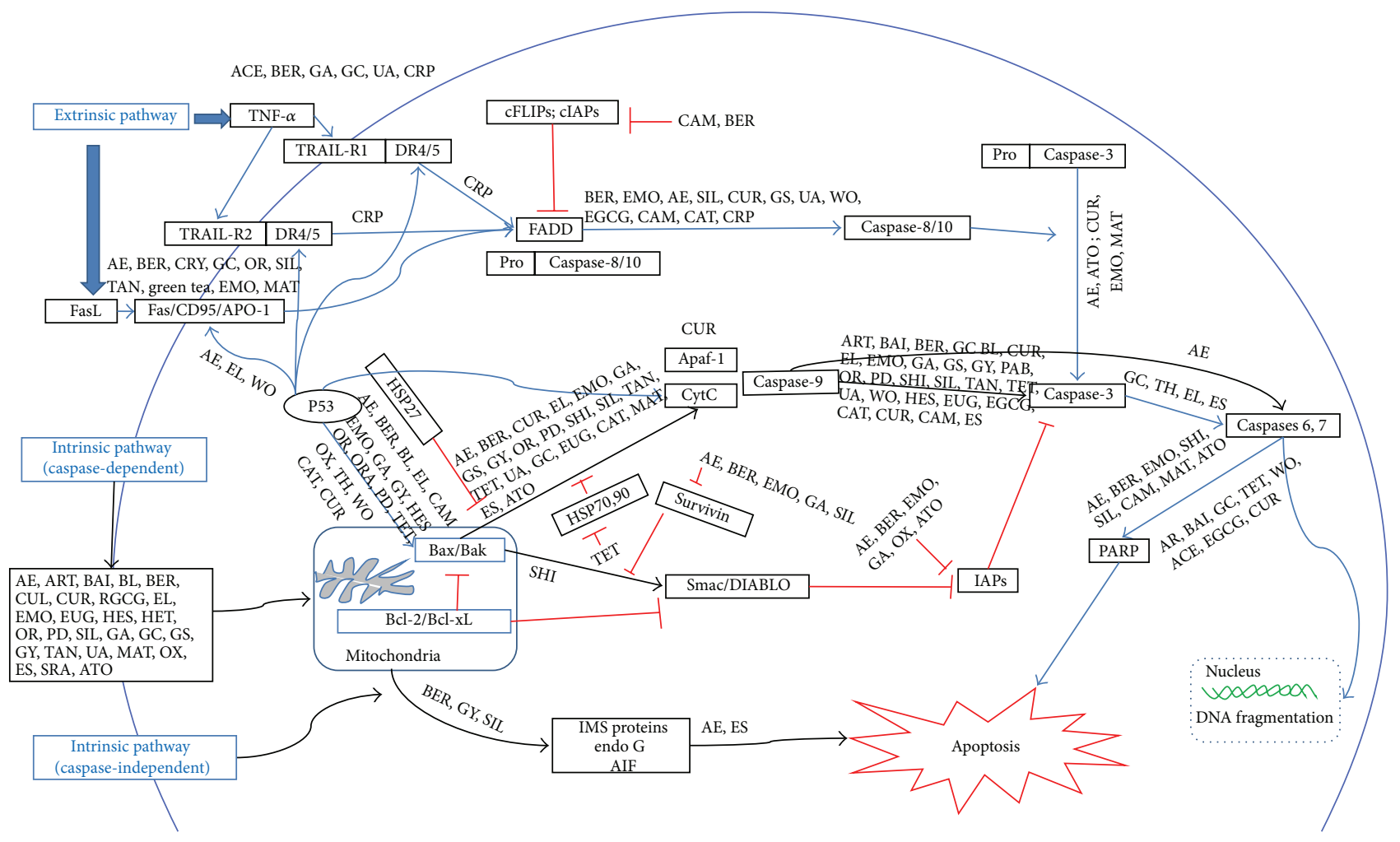

FIGURE 1: Schematic diagram of the mechanisms of CMs-induced cancer apoptosis. ACE: $1^{\prime} S-1^{\prime}$-acetoxyeugenol acetate; AE: aloe emodin; ART: artemisinins; ATO: arsenic trioxide; BAI: baicalin; BL: baicalein; BER: berberine; CAM: camptothecin; CAT: catechins; CRP: cryptocaryone; CRY: cryptotanshinone; CUR: curcumin; CUL: curcumol; EL: $\beta$-elemene; EGCG: (-)epicatechin-3-gallate and polyphenols; EMO: Emodin; ES: extract of shizhuyu; EUG: eugenol; GA: gambogic acid; GC: gancao; GS: Ginseng; GY: gypenosides, HES: hesperidin; HET: hesperetin; MAT: matrine; OR: oridonin; ORA: oroxylin A; OX: oxymatrine; PD: polyphyllin D; PAB: pseudolaric acid B; SHI: shikonin; SIL: silibinin; SRA: selenium-rich amino acids; TAN: tanshinone IIA; TET: tetrandrine; TH: total huangqin glucosides; TRI: triptolide; UA: ursolic acid; WO: wogonin.

$[4,5,12]$ (Figure 2). We previously reported that fangchinoline (isolated from Fangji, Stephenia tetrandra S Moore) triggered autophagy in a dose-dependent manner on two human hepatocellular carcinoma cell lines, HepG2 and PLC/PRF/5. Blocking fangchinoline-induced autophagy process would alter the pathway of cell death leading to apoptosis; thus cell death was an irreversible process induced by fangchinoline [34]. Cheng et al. reported that the exposure of murine fibrosarcoma L929 cells to oridonin led to the release of cytochrome $c$, translocation of Bax, and generation of ROS. Additionally, oridonin induced autophagy in L929 cells through p38 and NK- $\kappa$ B pathways. Autophagy occurred after oridonin treatment and blocking autophagy caused apoptosis $[39,40]$. These observations suggested that autophagic cell death governed the cell fate upon CMs treatment. General information of CMs inducing autophagic cell death is summarized in Table 1. Figure 2 further illustrates the mechanisms of some representative CMs inducing autophagic cell death.

2.3. CMs Induce Necrotic Cancer Cell Death. Necrosis is classified as nonprogrammed cell death in the absence of morphological traits of apoptosis or autophagy. This phenomenon gives rise to "uncontrolled" cell death, loss of ATP, and membrane pumps [4]. In contrast to these features, recent study showed that necrosis exhibited its regulated characteristic, in other words, necroptosis [9]. This process involved alkylating DNA damage, excitotoxins, and ligation of death receptors under some conditions, which depended on the serine/threonine kinase activity of RIP1, target of a new cytoprotective agent, necrostatins. Others that affected the execution of necroptosis were named cyclophilin D, poly (ADP-ribose) polymerase 1 (PARP-1), and AIF [145]. Several researches on CMs have focused on the study of necrosis or necroptosis. Shikonin, a component extracted from Lithospermum erythrorhizon Siebold \& Zucc. (Zicao), has been found to induce necrotic cell death in MCF-7 and HEK293. Han et al. reported that cell death pathway of shikonintreated cells was different from either apoptosis or autophagic cell death in which loss of plasma membrane integrity was one of the morphology of necrotic cell death, but loss of $\Delta \psi$ and elevation of ROS did not critically contribute to cell death due to the protection by necrostatin-1 $[106,107]$. ROS and $\mathrm{Ca}^{2+}$ elevated permeability transition pore complex- (PTPC) dependent mitochondrial permeability transition (which was also induced by RIP1), while necrostatin-1 specifically prevented the cells from necroptosis. In summary, shikonin could induce cancer cells into necroptosis. 


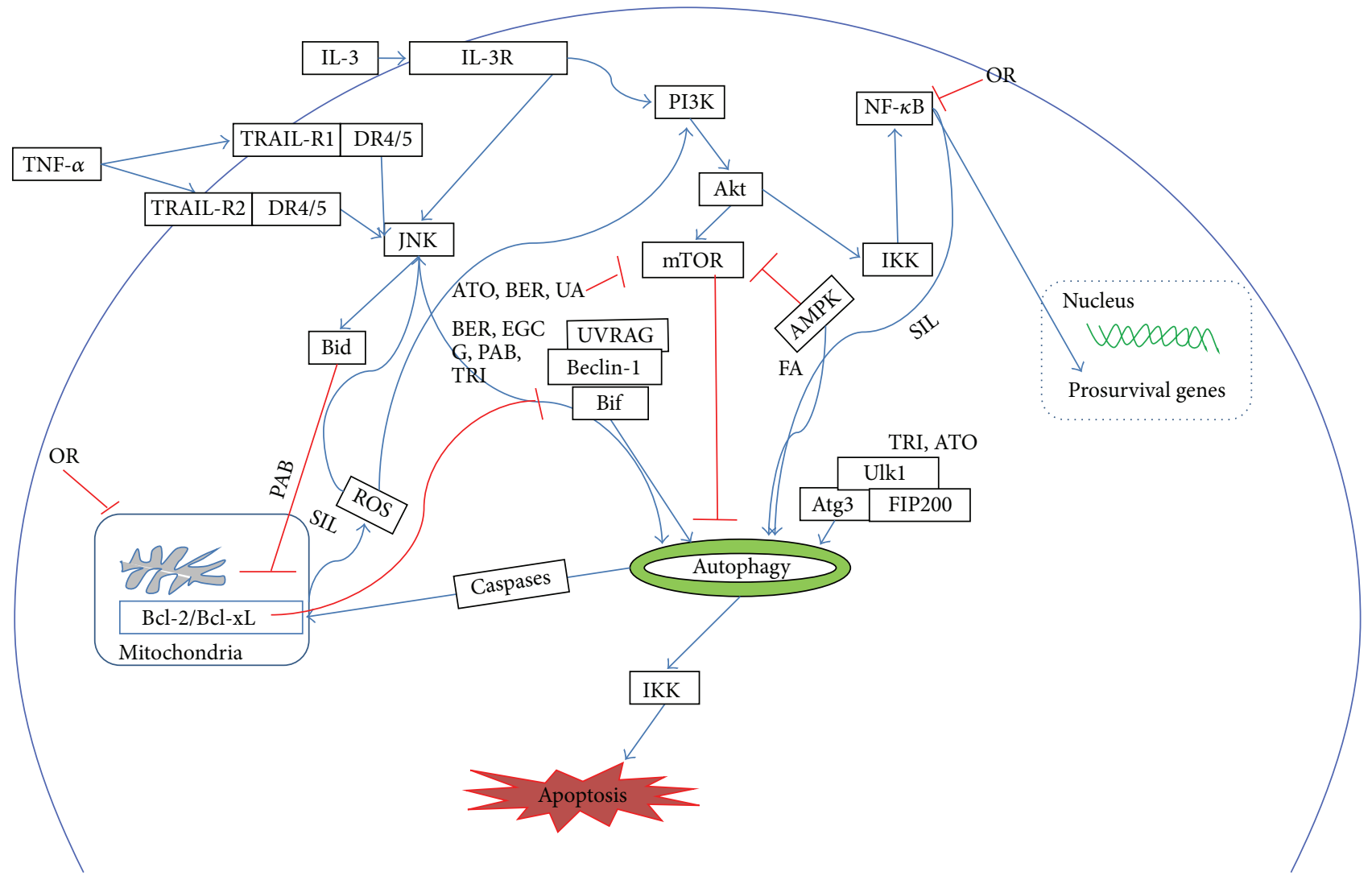

FIGURE 2: Schematic diagram of the mechanisms of the CMs for cancer autophagy death. AE: aloe emodin; ATO: arsenic trioxide; BER: berberine, EGCG: (-)epicatechin-3-gallate and polyphenols; FA: fangchinoline; OR: oridonin; PAB: pseudolaric acid BSIL: silibinin; TRI: triptolide; UA: ursolic acid.

Arsenic trioxide, another popular CM (Chinese name: Pishuang), also induced necrosis in the dose of $1 \mathrm{mg} / \mathrm{kg}$ accompanied by a sharp decrease of proliferation index in HCC cells [126]. Mercer et al. reported that treatment of artesunate $(50 \mu \mathrm{m}, 48 \mathrm{~h})$, an artemisinin from Artemisia annua L. (Chinese name: Qinghao), induced $24 \pm 9 \%$ of necrotic/late apoptotic in HeLa cells and $67 \pm 21 \%$ necrotic in HeLa $\rho^{0}$ cells. These data suggested that induced necrosis was associated with low levels of ATP and defective apoptotic mechanisms in some cancer lines [21]. Table 1 shows general information of CMs-induced necrotic cell death. Figure 3 illustrates the mechanisms of some representative CMsinduced necrotic cell death.

\section{Discussion}

As one of the typical cancer hallmarks, cell death has attracted great attention in recent years and the study of this biological process with intervention of CMs will explore a novel way to treat cancers clinically. However, many CMs have not been approved for clinical use yet. To further investigate the efficacy and toxicity of CMs, further researches and clinical trials are necessary. In addition, a lot of CMs have been directly used as composite formula in cancer clinics according to Chinese medicine's theories for centuries. However, limited composite formula-induced anticancer action via cell death pathway is known and only few researches have been conducted from in vitro study, for example, Huang-lian-jie-dutang (Japanese name: oren-gedoku-to) induced apoptotic cell death in human myeloma cells [146], HepG2, and PLC/PRF/5 cells [147]. More studies on composite Chinese medicine formula with good quality control would be needed at the molecular and cellular level.

As mentioned above, CM may exhibit integrated or additive anticancer effect through two or more subpathways. Triptolide (from Leigongteng, Tripterygium wilfordii Hook. f.) could induce both caspase-dependent and -independent apoptotic cell death by activating caspase- 3 , caspase- 8 , and caspase- 9 and Bax but decreasing Bcl-2 [36-38, 113, 148-152]. These studies indicated that CMs might function on multiple modes in cancer cells which need further studies [12, 153] (Figure 1). With regard to cell deaths, through integrated or additive effect, we have conducted a study to explore how berberine (from Huanglian, Coptis chinensis Franch) induced cell death in human liver cancer cells, HepG2, and MHCC97-L. We found that the chemical induced both apoptosis and autophagy, in which autophagy accounts for 


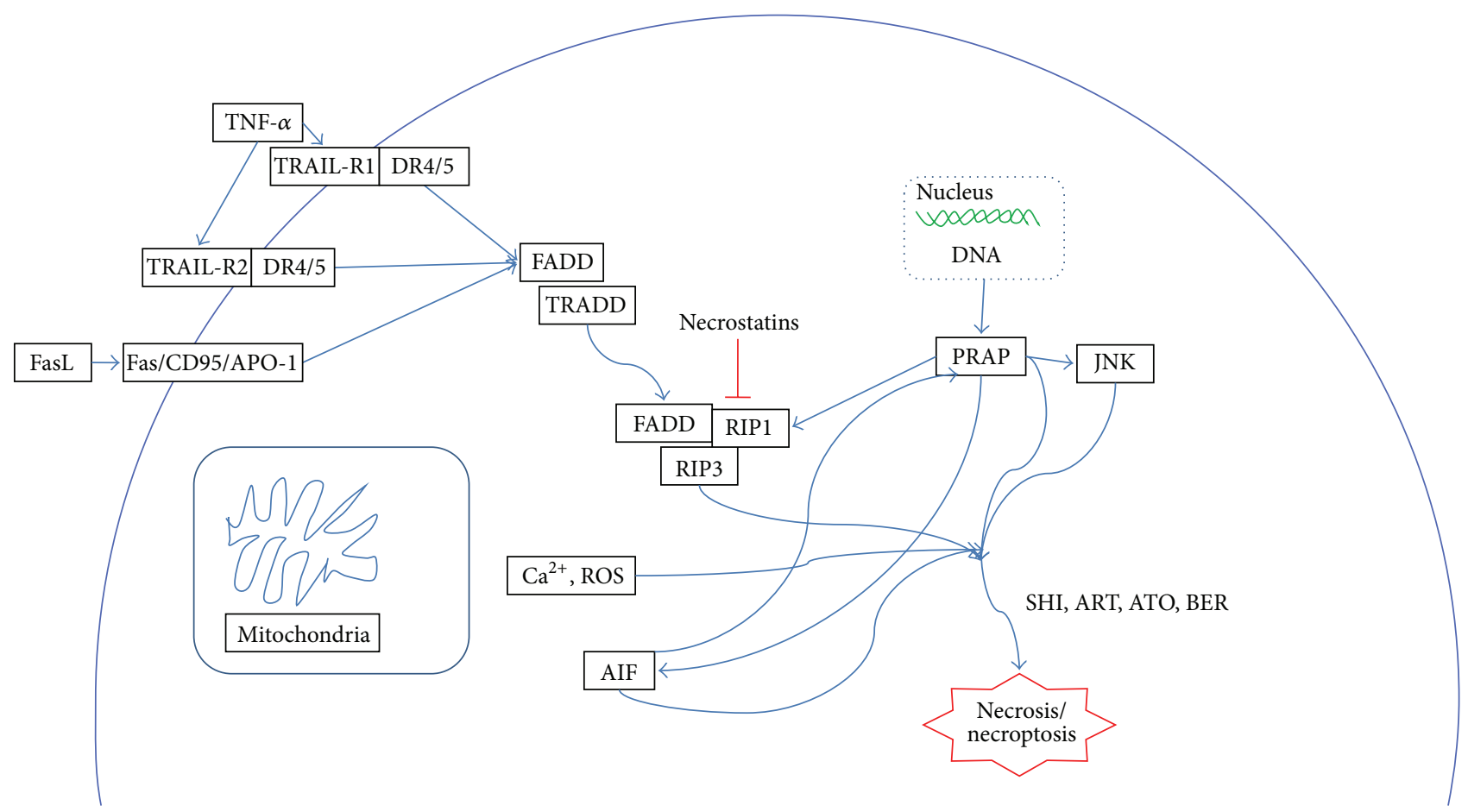

FIgURE 3: Schematic diagram of the mechanisms of CMs for cancer necrotic/necroptotic death. ART: artemisinins; ATO: arsenic trioxide; BER: berberine; SHI: shikonin.

$30 \%$ of berberine-induced HepG2 cell death, while apoptosis was responsible for the most contribution to liver cancer cell death. With regard to the underlying mechanism of berberine-induced autophagic and apoptotic cell death, our data demonstrated it could induce Bax activation, formation of PTPC, reduction of $\Delta \psi$, and release of cytochrome $c$ and Beclin-1 [111]. Similar to apoptosis, autophagy and necrosis/necroptosis affect PTPC, ROS, $\mathrm{Ca}^{2+}, \mathrm{Bcl}-2, \mathrm{Bax}$, AIF, PARP, and other cytokines during programmed cell death; it was reported that berberine induced necrosis in B16 cells [112]. But it is unknown whether berberine can induce programmed necrosis in HepG2. The cross talk among the three cell death pathways may lead to therapeutic implications. For instance, the selective inhibition of necrosis or apoptotic cell death may defend inflammation and thereby reduce subsequent tissue damage. Besides, it may serve as a novel therapeutic strategy by inducing necrotic cell death on apoptosis resistant cancer cells [109, 145].

The effectiveness of cancer chemotherapy significantly depends on apoptosis in cancer cells, while the significance of autophagy and necrosis in cancer therapy needs to be further clarified. Several reports showed that some CMs induced autophagy and inhibited cell apoptosis [30, 37, 45-48]. In contrast, some may induce autophagy leading to apoptosis $[36,41,111]$. In this context, autophagy might act as a housekeeper which eliminated abnormal proteins and recycles materials during cell starvation $[7,154]$. Cell death pathway could switch to apoptosis or necrosis by inhibiting autophagy $[4,9]$. However, the molecular mechanism between apoptosis and programmed necrosis (or necroptosis) is still unclear.
In addition to the above three types of cell death, there are other new types of cell death. Ginsenoside Rh2 (From Renshen) exhibited significant effects on cell death in colorectal cancer cells, HCT116 and SW480. Besides inducing apoptosis through activation of p53 pathway, Ginsenoside Rh2 also increased visible cytoplasmic vacuolization in HCT116 cells, which were blocked by cycloheximide (CHX), a protein synthesis inhibitor. Due to the characteristic of paraptosis as visible cytoplasmic vacuolization without disruption of the cell membrane $[155,156]$, Ginsenoside $\mathrm{Rh} 2$ was proposed as a paraptosis-like cell death inducer $[42,58,59]$. Berberine and a modified Chinese formula, Yi Guan Jian, might induce cancer cell anoikis [113, 149, 157]. Pharicin A (from Xiangchacai, Isodon amethystoides (Benth.) H. Hara) [123] and casticin (from Manjing, Vitex rotundifolia L.f.) [124] initiated mitotic catastrophe in cancer. Apart from the above-mentioned cell death, several other cell death pathways such as cornification, entosis, netosis, parthanatos, and pyroptosis have also been discussed elsewhere [4, 9-12]. However, to the best of our knowledge, none of the CMs is found to be involved in these novel pathways.

In summary, this paper reviewed 45 pure compounds and extracts from CMs which can induce different cancer cell death and the underlying mechanisms. The overview of the flow chart is shown in Figure 4. Apparently, cell death is not only one mechanism of all these pure compounds and extracts for cancer therapy, but also via other mechanisms such as antiproliferation, anti-invasion, anti-angiogenesis, and anti-inflammation [15]. Since the natural sources of CMs are raw or processed materials focusing on low- or nontoxic 


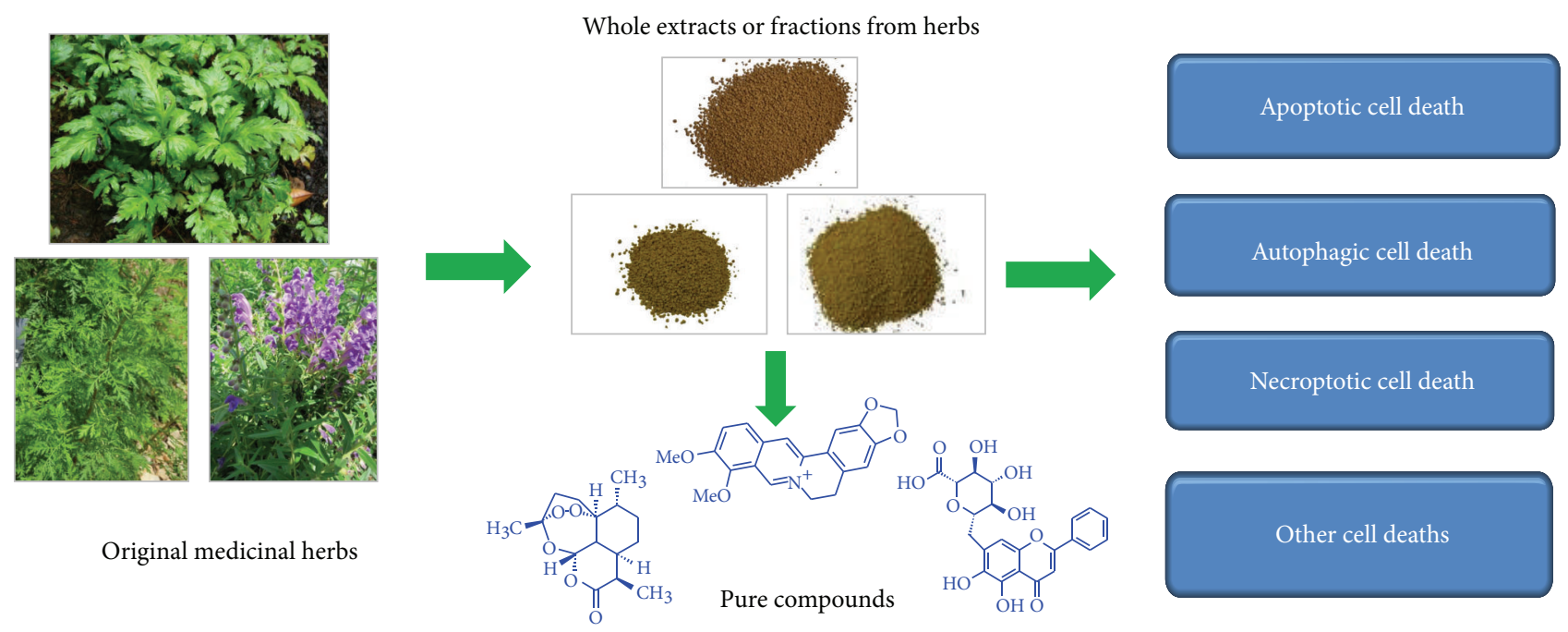

Figure 4: The overview of the flow chart for this review paper. The paper reviewed 45 pure compounds and extracts from CMs which can induce different cancer cell death.

dosages, while all these CMs in this review are pure single compounds or extracts which induce cell death by cytotoxic dosage, we should pay attention to careful explanation of the results of all these CMs. Basically, CM practitioners do not use pure compounds to treat diseases, but CM practitioners begin to integrate traditional use with results derived from modern research including characteristics of CMs inducing cell death for cancer therapy in recent years. For example, berberine, a main active compound of huanglian, is not directly used in CM clinical practice, but the various effects of berberine in cancer cell models will bring some new insight into clinical usage of huanglian when CM practitioners use huanglian combined with other herbs to treat cancer Tang et al., [158]. Usually, huanglian was used in low dosage 2$5 \mathrm{~g}$ to treat diseases, while high dosage of huanglian at 15$30 \mathrm{~g}$ was also suggested for use in recent years because we found that berberine could inhibit cancer cell migration in low dosage, while berberine could induce cell death in high dosage with safety Tang et al., [15, 111, 158]. For the high dosage of huanglian, it needs further validation by clinical study. On the other hand, limited composite formula-induced anticancer action via cell death pathway is known and only few researches have been conducted from in vitro study; more studies on composite Chinese medicine formula with good quality control would be needed at the molecular and cellular level and clinical studies.

\section{Conclusions}

This review showed that CMs treatment could induce multiple cancer cell death pathways including apoptosis, autophagy, necrosis, and other kinds of cell death, in which apoptosis is the most dominant type. How to apply these preclinical researches to clinical application will be a key issue in the future. The summary about CMs inducing cell death in this systematic review may offer insight into future development of cancer drug discovery from CMs and clinical application of CMs in cancer treatment.

\section{Conflict of Interests}

The authors declare there is no conflict of interests regarding the publication of this paper.

\section{Acknowledgments}

The study was financially supported by Grants from the research council of the University of Hong Kong (Project Codes: 10401764 and 104002889), the Open Project of Hubei Key Laboratory of Wudang Local Chinese Medicine Research, Hubei University of Medicine (Grant no. WDCM001), and The Research Grant Committee (RGC) of Hong Kong (RGC General Research Fund, Project Code: 10500362).

\section{References}

[1] A. Jemal, F. Bray, M. M. Center, J. Ferlay, E. Ward, and D. Forman, "Global cancer statistics," CA: A Cancer Journal for Clinicians, vol. 61, no. 2, pp. 69-90, 2011.

[2] D. Hanahan and R. A. Weinberg, "Hallmarks of cancer: the next generation," Cell, vol. 144, no. 5, pp. 646-674, 2011.

[3] P. G. H. Clarke, "Developmental cell death: morphological diversity and multiple mechanisms," Anatomy and Embryology, vol. 181, no. 3, pp. 195-213, 1990.

[4] R. A. Lockshin and Z. Zakeri, "Apoptosis, autophagy, and more," The International Journal of Biochemistry and Cell Biology, vol. 36, no. 12, pp. 2405-2419, 2004.

[5] A. L. Edinger and C. B. Thompson, "Death by design: apoptosis, necrosis and autophagy," Current Opinion in Cell Biology, vol. 16, no. 6, pp. 663-669, 2004.

[6] J. F. Kerr, A. H. Wyllie, and A. R. Currie, "Apoptosis: a basic biological phenomenon with wide-ranging implications 
in tissue kinetics," British Journal of Cancer, vol. 26, no. 4, pp. 239-257, 1972.

[7] C. W. Wang and D. J. Klionsky, "The molecular mechanism of autophagy," Molecular Medicine, vol. 9, no. 3-4, pp. 65-76, 2003.

[8] A. Degterev, Z. Huang, M. Boyce et al., "Chemical inhibitor of nonapoptotic cell death with therapeutic potential for ischemic brain injury," Nature Chemical Biology, vol. 1, no. 2, pp. 112-119, 2005.

[9] L. Galluzzi, I. Vitale, J. M. Abrams et al., "Molecular definitions of cell death subroutines: recommendations of the Nomenclature Committee on Cell Death 2012," Cell Death and Differentiation, vol. 19, no. 1, pp. 107-120, 2012.

[10] F. Margottin-Goguet, J. Y. Hsu, A. Loktev, H. Hsieh, J. D. R. Reimann, and P. K. Jackson, "Prophase destruction of Emil by the SCF $\beta \operatorname{TrCP} /$ Slimb ubiquitin ligase activates the anaphase promoting complex to allow progression beyond prometaphase," Developmental Cell, vol. 4, no. 6, pp. 813-826, 2003.

[11] I. B. Roninson, E. V. Broude, and B. D. Chang, "If not apoptosis, then what? Treatment-induced senescence and mitotic catastrophe in tumor cells," Drug Resistance Updates, vol. 4, no. 5, pp. 303-313, 2001.

[12] C. K. Speirs, M. Hwang, S. Kim et al., "Harnessing the cell death pathway for targeted cancer treatment," The American Journal of Cancer Research, vol. 1, no. 1, pp. 43-61, 2011.

[13] R. V. Ancuceanu and V. Istudor, "Pharmacologically active natural compounds for lung cancer," Alternative Medicine Review, vol. 9, no. 4, pp. 402-419, 2004.

[14] B. Carmady and C. A. Smith, "Use of Chinese medicine by cancer patients: a review of surveys," Chinese Medicine, vol. 6, article 22, 2011.

[15] Y. Feng, N. Wang, M. Zhu, H. Li, and S. Tsao, "Recent progress on anticancer candidates in patents of herbal medicinal products," Recent Patents on Food, Nutrition \& Agriculture, vol. 3, no. 1, pp. 30-48, 2011.

[16] Y.-H. Lin and J.-H. Chiu, "Use of Chinese medicine among patients with liver cancer in Taiwan," Journal of Alternative and Complementary Medicine, vol. 16, no. 5, pp. 527-528, 2010.

[17] C. Y. Pu, V. M. Lan, C. F. Lan, and H. C. Lang, "The determinants of traditional Chinese medicine and acupuncture utilization for cancer patients with simultaneous conventional treatment," European Journal of Cancer Care, vol. 17, no. 4, pp. 340-349, 2008.

[18] L. C. Wong, E. Chan, S. Tay, K. M. Lee, and M. Back, "Complementary and alternative medicine practices among Asian radiotherapy patients," Asia-Pacific Journal of Clinical Oncology, vol. 6, no. 4, pp. 357-363, 2010.

[19] M. P. Crespo-Ortiz and M. Q. Wei, "Antitumor activity of artemisinin and its derivatives: from a well-known antimalarial agent to a potential anticancer drug," Journal of Biomedicine and Biotechnology, vol. 2012, Article ID 247597, 18 pages, 2012.

[20] H. Lai, I. Nakase, E. Lacoste, N. P. Singh, and T. Sasaki, "Artemisinin-transferrin conjugate retards growth of breast tumors in the rat," Anticancer Research, vol. 29, no. 10, pp. 38073810, 2009.

[21] A. E. Mercer, I. M. Copple, J. L. Maggs, P. M. O’Neill, and B. K. Park, "The role of heme and the mitochondrion in the chemical and molecular mechanisms of mammalian cell death induced by the artemisinin antimalarials," The Journal of Biological Chemistry, vol. 286, no. 2, pp. 987-996, 2011.
[22] Y. Gong, Y. Li, Y. Lu et al., "Bioactive tanshinones in Salvia miltiorrhiza inhibit the growth of prostate cancer cells in vitro and in mice," International Journal of Cancer, vol. 129, no. 5, pp. 1042-1052, 2011.

[23] H. L. Tian, T. Yu, N. N. Xu et al., "A novel compound modified from tanshinone inhibits tumor growth in vivo via activation of the intrinsic apoptotic pathway," Cancer Letters, vol. 297, no. 1, pp. 18-30, 2010.

[24] S.-H. Won, H.-J. Lee, S.-J. Jeong et al., “Tanshinone IIa induces mitochondria dependent apoptosis in prostate cancer cells in association with an inhibition of phosphoinositide 3kinase/AKT pathway," Biological and Pharmaceutical Bulletin, vol. 33, no. 11, pp. 1828-1834, 2010.

[25] I. J. Park, M. J. Kim, O. J. Park et al., "Cryptotanshinone sensitizes DU145 prostate cancer cells to Fas(APO1/CD95)mediated apoptosis through Bcl-2 and MAPK regulation," Cancer Letters, vol. 298, no. 1, pp. 88-98, 2010.

[26] J. Yu, X. Li, S. Tashiro, S. Onodera, and T. Ikejima, "Bcl-2 family proteins were involved in pseudolaric acid B-induced autophagy in murine fibrosarcoma L929 cells," Journal of Pharmacological Sciences, vol. 107, no. 3, pp. 295-302, 2008.

[27] K.-S. Li, X.-F. Gu, P. Li et al., "Effect of pseudolaric acid B on gastric cancer cells: inhibition of proliferation and induction of apoptosis," The World Journal of Gastroenterology, vol. 11, no. 48, pp. 7555-7559, 2005.

[28] V. K. W. Wong, P. Chiu, S. S. M. Chung et al., "Pseudolaric acid $\mathrm{B}$, a novel microtubule-destabilizing agent that circumvents multidrug resistance phenotype and exhibits antitumor activity in vivo," Clinical Cancer Research, vol. 11, no. 16, pp. 6002-6011, 2005.

[29] R. E. de Angel, S. M. Smith, R. D. Glickman, S. N. Perkins, and S. D. Hursting, "Antitumor effects of ursolic acid in a mouse model of postmenopausal breast cancer," Nutrition and Cancer, vol. 62, no. 8, pp. 1074-1086, 2010.

[30] S. W. Shin, S. Y. Kim, and J. Park, "Autophagy inhibition enhances ursolic acid-induced apoptosis in PC3 cells," Biochimica et Biophysica Acta, vol. 1823, no. 2, pp. 451-457, 2012.

[31] K. H. Kim, H. S. Seo, H. S. Choi, I. H. Choi, Y. C. Shin, and S.-G. Ko, "Induction of apoptotic cell death by ursolic acid through mitochondrial death pathway and extrinsic death receptor pathway in MDA-MB-231 cells," Archives of Pharmacal Research, vol. 34, no. 8, pp. 1363-1372, 2011.

[32] S. H. Kwon, H. Y. Park, J. Y. Kim, I. Y. Jeong, M. K. Lee, and K. I. Seo, "Apoptotic action of ursolic acid isolated from Corni fructus in $\mathrm{RC}-58 \mathrm{~T} / \mathrm{h} / \mathrm{SA} \# 4$ primary human prostate cancer cells," Bioorganic and Medicinal Chemistry Letters, vol. 20, no. 22, pp. 6435-6438, 2010.

[33] A. Pinon, Y. Limami, L. Micallef et al., "A novel form of melanoma apoptosis resistance: melanogenesis up-regulation in apoptotic B16-F0 cells delays ursolic acid-triggered cell death," Experimental Cell Research, vol. 317, no. 12, pp. 16691676, 2011.

[34] N. Wang, W. Pan, M. Zhu et al., "Fangchinoline induces autophagic cell death via p53/sestrin2/AMPK signalling in human hepatocellular carcinoma cells," The British Journal of Pharmacology, vol. 164, no. 2, pp. 731-742, 2011.

[35] S.-L. Yan, C.-Y. Huang, S.-T. Wu, and M.-C. Yin, "Oleanolic acid and ursolic acid induce apoptosis in four human liver cancer cell lines," Toxicology in Vitro, vol. 24, no. 3, pp. 842-848, 2010.

[36] N. Mujumdar and A. K. Saluja, "Autophagy in pancreatic cancer: an emerging mechanism of cell death," Autophagy, vol. 6, no. 7, pp. 997-998, 2010. 
[37] L. Chen, Q. Liu, Z. Huang et al., "Tripchlorolide induces cell death in lung cancer cells by autophagy," International Journal of Oncology, vol. 40, no. 4, pp. 1066-1070, 2012.

[38] K. A. Clawson, D. Borja-Cacho, M. B. Antonoff, A. K. Saluja, and S. M. Vickers, "Triptolide and TRAIL combination enhances apoptosis in cholangiocarcinoma," Journal of Surgical Research, vol. 163, no. 2, pp. 244-249, 2010.

[39] Y. Cheng, F. Qiu, and T. Ikejima, "Molecular mechanisms of oridonin-induced apoptosis and autophagy in murine fibrosarcoma L929 cells," Autophagy, vol. 5, no. 3, pp. 430-431, 2009.

[40] Y. Cheng, F. Qiu, Y.-C. Ye et al., "Autophagy inhibits reactive oxygen species-mediated apoptosis via activating p38-nuclear factor-kappa B survival pathways in oridonin-treated murine fibrosarcoma L929 cells," FEBS Journal, vol. 276, no. 5, pp. 12911306, 2009.

[41] Q. Cui, S. Tashiro, S. Onodera, M. Minami, and T. Ikejima, "Autophagy preceded apoptosis in oridonin-treated human breast cancer MCF-7 cells," Biological and Pharmaceutical Bulletin, vol. 30, no. 5, pp. 859-864, 2007.

[42] C. Li, E. Wang, Y. Cheng, and J. Bao, "Oridonin: an active diterpenoid targeting cell cycle arrest, apoptotic and autophagic pathways for cancer therapeutics," International Journal of Biochemistry and Cell Biology, vol. 43, no. 5, pp. 701-704, 2011.

[43] S. Chen, M. Cooper, M. Jones et al., "Combined activity of oridonin and wogonin in advanced-stage ovarian cancer cells," Cell Biology and Toxicology, vol. 27, no. 2, pp. 133-147, 2011.

[44] N. Kang, J. Zhang, F. Qiu, S. Tashiro, S. Onodera, and T. Ikejima, "Inhibition of EGFR signaling augments oridonininduced apoptosis in human laryngeal cancer cells via enhancing oxidative stress coincident with activation of both the intrinsic and extrinsic apoptotic pathways," Cancer Letters, vol. 294, no. 2, pp. 147-158, 2010.

[45] A. Liu, H. Chen, H. Tong et al., "Emodin potentiates the antitumor effects of gemcitabine in pancreatic cancer cells via inhibition of nuclear factor- $\kappa \mathrm{B}$," Molecular Medicine Reports, vol. 4, no. 2, pp. 221-227, 2011.

[46] B. Liu, P. Yang, Y. Ye et al., "Role of ROS in the protective effect of silibinin on sodium nitroprusside-induced apoptosis in rat pheochromocytoma PC12 cells," Free Radical Research, vol. 45, no. 7, pp. 835-847, 2011.

[47] J. Liu, Y. Zhang, J. Qu et al., “ $\beta$-Elemene-induced autophagy protects human gastric cancer cells from undergoing apoptosis," BMC Cancer, vol. 11, article 183, 2011.

[48] L. Liu, C. Chen, W. Gong et al., "Epoxyeicosatrienoic acids attenuate reactive oxygen species level, mitochondrial dysfunction, caspase activation, and apoptosis in carcinoma cells treated with arsenic trioxide," Journal of Pharmacology and Experimental Therapeutics, vol. 339, no. 2, pp. 451-463, 2011.

[49] X. Peng, Y. Zhao, X. Liang et al., "Assessing the quality of RCTs on the effect of $\beta$-elemene, one ingredient of a Chinese herb, against malignant tumors," Contemporary Clinical Trials, vol. 27, no. 1, pp. 70-82, 2006.

[50] W. Zhang, Z. Wang, and T. Chen, "Curcumol induces apoptosis via caspases-independent mitochondrial pathway in human lung adenocarcinoma ASTC-a-1 cells," Medical Oncology, vol. 28, no. 1, pp. 307-314, 2011.

[51] S. H. Cho, K. S. Chung, J. H. Choi, D. H. Kim, and K. T. Lee, "Compound $\mathrm{K}$, a metabolite of ginseng saponin, induces apoptosis via caspase-8-dependent pathway in HL-60 human leukemia cells," BMC Cancer, vol. 9, article 149, 2009.
[52] D. Y. Kim, M. W. Park, H. D. Yuan, H. J. Lee, S. H. Kim, and S. H. Chung, "Compound $\mathrm{K}$ induces apoptosis via CAMKIV/AMPK pathways in HT-29 colon cancer cells," Journal of Agricultural and Food Chemistry, vol. 57, no. 22, pp. 1057310578, 2009.

[53] J. I. Lee, Y. W. Ha, T. W. Choi et al., "Cellular uptake of ginsenosides in korean white ginseng and red ginseng and their apoptotic activities in human breast cancer cells," Planta Medica, vol. 77, no. 2, pp. 133-140, 2011.

[54] S. Park, H.-J. Lee, S.-J. Jeong et al., "Inhibition of JAK1/STAT3 signaling mediates compound $\mathrm{K}$-induced apoptosis in human multiple myeloma U266 cells," Food and Chemical Toxicology, vol. 49, no. 6, pp. 1367-1372, 2011.

[55] G. Song, S. Guo, W. Wang et al., "Intestinal metabolite compound $\mathrm{K}$ of ginseng saponin potently attenuates metastatic growth of hepatocellular carcinoma by augmenting apoptosis via a bid-mediated mitochondrial pathway," Journal of Agricultural and Food Chemistry, vol. 58, no. 24, pp. 12753-12760, 2010.

[56] J. Jian, Z. Hu, and Y. Huang, "Effect of ginsenoside Rg3 on Pim-3 and Bad proteins in human pancreatic cancer cell line PANC-1," Chinese Journal of Cancer, vol. 28, no. 5, pp. 461-465, 2009.

[57] S. M. Kim, S. Y. Lee, D. Y. Yuk et al., "Inhibition of NF- $\kappa$ B by ginsenoside $\mathrm{Rg} 3$ enhances the susceptibility of colon cancer cells to docetaxel," Archives of Pharmacal Research, vol. 32, no. 5, pp. 755-765, 2009.

[58] B. Li, J. Zhao, C.-Z. Wang et al., "Ginsenoside Rh2 induces apoptosis and paraptosis-like cell death in colorectal cancer cells through activation of p53," Cancer Letters, vol. 301, no. 2, pp. 185-192, 2011.

[59] W. Li, S. Zhu, J. Li et al., "EGCG stimulates autophagy and reduces cytoplasmic HMGB1 levels in endotoxin-stimulated macrophages," Biochemical Pharmacology, vol. 81, no. 9, pp. 1152-1163, 2011.

[60] S. Choi, J.-Y. Oh, and S.-J. Kim, "Ginsenoside Rh2 induces Bcl2 family proteins-mediated apoptosis in vitro and in xenografts in vivo models," Journal of Cellular Biochemistry, vol. 112, no. 1, pp. 330-340, 2011.

[61] J.-H. Kang, K.-H. Song, J.-K. Woo et al., "Ginsenoside Rp1 from Panax ginseng exhibits anti-cancer activity by down-regulation of the IGF-1R/Akt pathway in breast cancer cells," Plant Foods for Human Nutrition, vol. 66, no. 3, pp. 298-305, 2011.

[62] A. Kumar, M. Kumar, T.-Y. Park et al., "Molecular mechanisms of ginsenoside Rp1-mediated growth arrest and apoptosis," International Journal of Molecular Medicine, vol. 24, no. 3, pp. 381-386, 2009.

[63] W. H. Lee, J. S. Choi, H. Y. Kim et al., "Potentiation of etoposideinduced apoptosis in HeLa cells by co-treatment with KG-135, a quality-controlled standardized ginsenoside formulation," Cancer Letters, vol. 294, no. 1, pp. 74-81, 2010.

[64] R. C. Y. Ong, J. Lei, R. K. Y. Lee et al., "Polyphyllin D induces mitochondrial fragmentation and acts directly on the mitochondria to induce apoptosis in drug-resistant HepG2 cells," Cancer Letters, vol. 261, no. 2, pp. 158-164, 2008.

[65] F. M. Siu, D. L. Ma, Y. W. Cheung et al., "Proteomic and transcriptomic study on the action of a cytotoxic saponin (Polyphyllin D): induction of endoplasmic reticulum stress and mitochondria-mediated apoptotic pathways," Proteomics, vol. 8 , no. 15, pp. 3105-3117, 2008.

[66] H.-Y. Hsu, J.-S. Yang, K.-W. Lu et al., "An experimental study on the antileukemia effects of gypenosides in vitro and in vivo," Integrative Cancer Therapies, vol. 10, no. 1, pp. 101-112, 2011. 
[67] J. Gao, W. A. Morgan, A. Sanchez-Medina, and O. Corcoran, "The ethanol extract of Scutellaria baicalensis and the active compounds induce cell cycle arrest and apoptosis including upregulation of p53 and Bax in human lung cancer cells," Toxicology and Applied Pharmacology, vol. 254, no. 3, pp. 221228, 2011.

[68] R.-H. Jiang, W.-C. Su, H.-F. Liu, H.-S. Huang, and J.-I. Chao, "Opposite expression of securin and $\gamma$-H2AX regulates baicalein-induced cancer cell death," Journal of Cellular Biochemistry, vol. 111, no. 2, pp. 274-283, 2010.

[69] H. N. Li, F. F. Nie, W. Liu et al., "Apoptosis induction of oroxylin A in human cervical cancer HeLa cell line in vitro and in vivo," Toxicology, vol. 257, no. 1-2, pp. 80-85, 2009.

[70] W. Liu, R. Mu, F. Nie et al., "MAC related mitochondrial pathway in oroxylin A induces apoptosis in human hepatocellular carcinoma HepG2 cells," Cancer Letters, vol. 284, no. 2, pp. 198207, 2009.

[71] G. Polier, J. Ding, B. V. Konkimalla et al., "Wogonin and related natural flavones are inhibitors of CDK9 that induce apoptosis in cancer cells by transcriptional suppression of Mcl-1," Cell Death and Disease, vol. 2, article e182, 2011.

[72] X. Xu, B. Cai, S. Guan et al., "Baicalin induces human mucoepidermoid carcinoma Mc3 cells apoptosis in vitro and in vivo," Investigational New Drugs, vol. 29, no. 4, pp. 637-645, 2011.

[73] X. Zhang, X. Tang, H. Liu, L. Li, Q. Hou, and J. Gao, "Autophagy induced by baicalin involves downregulation of CD147 in SMMC-7721 cells in vitro," Oncology Reports, vol. 27, no. 4, pp. 1128-1134, 2012.

[74] L. Yang, X. L. Zheng, H. Sun et al., "Catalase suppressionmediated $\mathrm{H} 2 \mathrm{O} 2$ accumulation in cancer cells by wogonin effectively blocks tumor necrosis factor-induced NF- $\kappa \mathrm{B}$ activation and sensitizes apoptosis," Cancer Science, vol. 102, no. 4, pp. 870876, 2011.

[75] W.-H. Yang, Y.-C. Fong, C.-Y. Lee et al., "Epigallocatechin-3gallate induces cell apoptosis of human chondrosarcoma cells through apoptosis signal-regulating kinase 1 pathway," Journal of Cellular Biochemistry, vol. 112, no. 6, pp. 1601-1611, 2011.

[76] E. J. Choi and G.-H. Kim, "Anti-/pro-apoptotic effects of hesperetin against 7,12-dimetylbenz(a) anthracene-induced alteration in animals," Oncology Reports, vol. 25, no. 2, pp. 545-550, 2011.

[77] R. V. Cluzan, F. Alliot, S. Ghabboun, and M. Pascot, “Treatment of secondary lymphedema of the upper limb with CYCLO 3 FORT," Lymphology, vol. 29, no. 1, pp. 29-35, 1996.

[78] M. Nazari, A. Ghorbani, A. Hekmat-Doost, M. Jeddi-Tehrani, and $\mathrm{H}$. Zand, "Inactivation of nuclear factor- $\kappa \mathrm{B}$ by citrus flavanone hesperidin contributes to apoptosis and chemosensitizing effect in Ramos cells," European Journal of Pharmacology, vol. 650, no. 2-3, pp. 526-533, 2011.

[79] C. S. Lee, Y. J. Kim, M. S. Lee, E. S. Han, and S. J. Lee, "18 $\beta$ Glycyrrhetinic acid induces apoptotic cell death in SiHa cells and exhibits a synergistic effect against antibiotic anti-cancer drug toxicity," Life Sciences, vol. 83, no. 13-14, pp. 481-489, 2008.

[80] B. J. Veldt, B. E. Hansen, K. Ikeda, E. Verhey, H. Suzuki, and S. W. Schalm, "Long-term clinical outcome and effect of glycyrrhizin in 1093 chronic hepatitis C patients with non-response or relapse to interferon," Scandinavian Journal of Gastroenterology, vol. 41, no. 9, pp. 1087-1094, 2006.

[81] M. Yoshikawa, M. Toyohara, S. Ueda et al., "Glycyrrhizin inhibits TNF-induced, but not Fas-mediated, apoptosis in the human hepatoblastoma line HepG2," Biological \& Pharmaceutical Bulletin, vol. 22, no. 9, pp. 951-955, 1999.
[82] N. Vidhya and S. Niranjali Devaraj, "Induction of apoptosis by eugenol in human breast cancer cells," Indian Journal of Experimental Biology, vol. 49, no. 11, pp. 871-878, 2011.

[83] L. L. Aun, M. N. Azmi, H. Ibrahim, K. Awang, and N. H. Nagoor, "1/S-1/-acetoxyeugenol acetate: a novel phenylpropanoid from Alpinia conchigera enhances the apoptotic effects of paclitaxel in MCF-7 cells through NF- $\kappa \mathrm{B}$ inactivation," Anti-Cancer Drugs, vol. 22, no. 5, pp. 424-434, 2011.

[84] J. Hoffmann, H. Junker, A. Schmieder et al., "EGCG downregulates IL-1RI expression and suppresses IL-1-induced tumorigenic factors in human pancreatic adenocarcinoma cells," Biochemical Pharmacology, vol. 82, no. 9, pp. 1153-1162, 2011.

[85] Y. C. Lim and Y. Y. Cha, "Epigallocatechin-3-gallate induces growth inhibition and apoptosis of human anaplastic thyroid carcinoma cells through suppression of EGFR/ERK pathway and cyclin B1/CDK1 complex," Journal of Surgical Oncology, vol. 104, no. 7, pp. 776-780, 2011.

[86] H. A. Vu, Y. Beppu, H. T. Chi et al., "Green tea epigallocatechin gallate exhibits anticancer effect in human pancreatic carcinoma cells via the inhibition of both focal adhesion kinase and insulin-like growth factor-I receptor," Journal of Biomedicine and Biotechnology, vol. 2010, Article ID 290516, 8 pages, 2010.

[87] A. A. Alshatwi, "Catechin hydrate suppresses MCF-7 proliferation through TP53/Caspase-mediated apoptosis," Journal of Experimental \& Clinical Cancer Research, vol. 29, no. 1, article 167,2010

[88] H. S. Oz and J. L. Ebersole, "Green tea polyphenols mediated apoptosis in intestinal epithelial cells by a FADD-dependent pathway," Journal of Cancer Therapy, vol. 1, no. 3, pp. 105-113, 2010.

[89] S. Tsukamoto, K. Hirotsu, M. Kumazoe et al., "Green tea polyphenol EGCG induces lipid-raft clustering and apoptotic cell death by activating protein kinase $C \delta$ and acid sphingomyelinase through a $67 \mathrm{kDa}$ laminin receptor in multiple myeloma cells," Biochemical Journal, vol. 443, no. 2, pp. 525-534, 2012.

[90] L.-Y. Wu, T. de Luca, T. Watanabe, D. M. Morré, and D. J. Morré, "Metabolite modulation of HeLa cell response to ENOX2 inhibitors EGCG and phenoxodiol," Biochimica et Biophysica Acta, vol. 1810, no. 8, pp. 784-789, 2011.

[91] Y. C. Chen, F. L. Kung, I. L. Tsai, T. H. Chou, I. S. Chen, and J. H. Guh, "Cryptocaryone, a natural dihydrochalcone, induces apoptosis in human androgen independent prostate cancer cells by death receptor clustering in lipid raft and nonraft compartments," The Journal of Urology, vol. 183, no. 6, pp. 24092418, 2010.

[92] R. E. Carroll, R. V. Benya, D. K. Turgeon et al., "Phase IIa clinical trial of curcumin for the prevention of colorectal neoplasia," Cancer Prevention Research, vol. 4, no. 3, pp. 354-364, 2011.

[93] J. H. Kim, S. C. Gupta, B. Park, V. R. Yadav, and B. B. Aggarwal, "Turmeric (Curcuma longa) inhibits inflammatory nuclear factor (NF)- $\kappa \mathrm{B}$ and NF- $\kappa \mathrm{B}$-regulated gene products and induces death receptors leading to suppressed proliferation, induced chemosensitization, and suppressed osteoclastogenesis," Molecular Nutrition \& Food Research, vol. 56, no. 3, pp. 454465, 2012.

[94] Y.-S. Ma, S.-W. Weng, M.-W. Lin et al., "Antitumor effects of emodin on LS1034 human colon cancer cells in vitro and in vivo: roles of apoptotic cell death and LS1034 tumor xenografts model," Food and Chemical Toxicology, vol. 50, no. 5, pp. 12711278, 2012. 
[95] H. Z. Lee, S. L. Hsu, M. C. Liu, and C. H. Wu, "Effects and mechanisms of aloe-emodin on cell death in human lung squamous cell carcinoma," European Journal of Pharmacology, vol. 431, no. 3, pp. 287-295, 2001.

[96] P. Suboj, S. Babykutty, P. Srinivas, and S. Gopala, "Aloe emodin induces G2/M cell cycle arrest and apoptosis via activation of caspase-6 in human colon cancer cells," Pharmacology, vol. 89, no. 1-2, pp. 91-98, 2012.

[97] H. Kauntz, S. Bousserouel, F. Gossé, and F. Raul, "Silibinin triggers apoptotic signaling pathways and autophagic survival response in human colon adenocarcinoma cells and their derived metastatic cells," Apoptosis, vol. 16, no. 10, pp. 1042-1053, 2011.

[98] R. P. Singh and R. Agarwal, "Prostate cancer prevention by silibinin," Current Cancer Drug Targets, vol. 4, no. 1, pp. 1-11, 2004.

[99] R. P. Singh and R. Agarwal, "Prostate cancer chemoprevention by silibinin: bench to bedside," Molecular Carcinogenesis, vol. 45, no. 6, pp. 436-442, 2006.

[100] J. Zeng, Y. Sun, K. Wu et al., "Chemopreventive and chemotherapeutic effects of intravesical silibinin against bladder cancer by acting on mitochondria," Molecular Cancer Therapeutics, vol. 10, no. 1, pp. 104-116, 2011.

[101] W. Duan, Q. Li, M. Xia, S. Tashiro, S. Onodera, and T. Ikejima, "Silibinin activated p53 and induced autophagic death in human fibrosarcoma HT1080 cells via reactive oxygen species-p38 and c-Jun N-terminal kinase pathways," Biological and Pharmaceutical Bulletin, vol. 34, no. 1, pp. 47-53, 2011.

[102] H. B. Huang, D. Chen, S. Li et al., "Gambogic acid enhances proteasome inhibitor-induced anticancer activity," Cancer Letters, vol. 301, no. 2, pp. 221-228, 2011.

[103] S. Kasibhatla, K. A. Jessen, S. Maliartchouk et al., "A role for transferrin receptor in triggering apoptosis when targeted with gambogic acid," Proceedings of the National Academy of Sciences of the United States of America, vol. 102, no. 34, pp. 12095-12100, 2005.

[104] M. K. Pandey, B. Sung, S. A. Kwang, A. B. Kunnumakkara, M. M. Chaturvedi, and B. B. Aggarwal, "Gambogic acid, a novel ligand for transferrin receptor, potentiates TNF-induced apoptosis through modulation of the nuclear factor- $\kappa \mathrm{B}$ signaling pathway," Blood, vol. 110, no. 10, pp. 3517-3525, 2007.

[105] R. Min, J. Tong, Y. Wenjun et al., "Growth inhibition and induction of apoptosis in human oral squamous cell carcinoma Tca8113 cell lines by Shikonin was partly through the inactivation of NF- $\kappa$ B pathway," Phytotherapy Research, vol. 22, no. 3, pp. 407415, 2008.

[106] W. Han, J. Xie, L. Li, Z. Liu, and X. Hu, "Necrostatin-1 reverts shikonin-induced necroptosis to apoptosis," Apoptosis, vol. 14, no. 5, pp. 674-686, 2009.

[107] W. Han, L. Li, S. Qiu et al., "Shikonin circumvents cancer drug resistance by induction of a necroptotic death," Molecular Cancer Therapeutics, vol. 6, no. 5, pp. 1641-1649, 2007.

[108] A. Burgeiro, C. Gajate, E. H. Dakir, J. A. Villa-Pulgarín, P. J. Oliveira, and F. Mollinedo, "Involvement of mitochondrial and B-RAF/ERK signaling pathways in berberine-induced apoptosis in human melanoma cells," Anti-Cancer Drugs, vol. 22, no. 6, pp. 507-518, 2011.

[109] K. N. Chidambara Murthy, G. K. Jayaprakasha, and B. S. Patil, "The natural alkaloid berberine targets multiple pathways to induce cell death in cultured human colon cancer cells," European Journal of Pharmacology, vol. 688, no. 1-3, pp. 14-21, 2012.
[110] P.-L. Peng, W.-H. Kuo, H.-C. Tseng, and F.-P. Chou, "Synergistic tumor-killing effect of radiation and berberine combined treatment in lung cancer: the contribution of autophagic cell death," International Journal of Radiation Oncology, Biology, Physics, vol. 70, no. 2, pp. 529-542, 2008.

[111] N. Wang, Y. Feng, M. Zhu et al., "Berberine induces autophagic cell death and mitochondrial apoptosis in liver cancer cells: the cellular mechanism," Journal of Cellular Biochemistry, vol. 111, no. 6, pp. 1426-1436, 2010.

[112] S. Letašiová, S. Jantová, L. Čipák, and M. Múčková, "Berberine-antiproliferative activity in vitro and induction of apoptosis/necrosis of the U937 and B16 cells," Cancer Letters, vol. 239, no. 2, pp. 254-262, 2006.

[113] J. B. Kim, J. H. Yu, E. Ko et al., "The alkaloid Berberine inhibits the growth of Anoikis-resistant MCF-7 and MDAMB-231 breast cancer cell lines by inducing cell cycle arrest," Phytomedicine, vol. 17, no. 6, pp. 436-440, 2010.

[114] H. El Btaouri, H. Morjani, Y. Greffe, E. Charpentier, and L. Martiny, "Role of JNK/ATF-2 pathway in inhibition of thrombospondin-1 (TSP-1) expression and apoptosis mediated by doxorubicin and camptothecin in FTC-133 cells," Biochimica et Biophysica Acta, vol. 1813, no. 5, pp. 695-703, 2011.

[115] Y. Zhang, C. Wang, H. Wang, K. Wang, Y. Du, and J. Zhang, "Combination of Tetrandrine with cisplatin enhances cytotoxicity through growth suppression and apoptosis in ovarian cancer in vitro and in vivo," Cancer Letters, vol. 304, no. 1, pp. 21-32, 2011.

[116] Z. J. Dai, J. Gao, Z. Z. Ji et al., "Matrine induces apoptosis in gastric carcinoma cells via alteration of Fas/FasL and activation of caspase-3," Journal of Ethnopharmacology, vol. 123, no. 1, pp. 91-96, 2009.

[117] T. Liu, Y. Song, H. Chen, S. Pan, and X. Sun, "Matrine inhibits proliferation and induces apoptosis of pancreatic cancer cells in vitro and in vivo," Biological and Pharmaceutical Bulletin, vol. 33, no. 10, pp. 1740-1745, 2010.

[118] Z. Lin, C.-F. Huang, X.-S. Liu, and J. Jiang, "In vitro anti-tumour activities of quinolizidine alkaloids derived from Sophora flavescens Ait," Basic \& Clinical Pharmacology \& Toxicology, vol. 108, no. 5, pp. 304-309, 2011.

[119] J.-Q. Zhang, Y.-M. Li, T. Liu et al., "Antitumor effect of matrine in human hepatoma G2 cells by inducing apoptosis and autophagy," The World Journal of Gastroenterology, vol. 16, no. 34, pp. 4281-4290, 2010.

[120] S. Zhang, J. Qi, L. Sun et al., "Matrine induces programmed cell death and regulates expression of relevant genes based on PCR array analysis in C6 glioma cells," Molecular Biology Reports, vol. 36, no. 4, pp. 791-799, 2009.

[121] Q. Ling, X. Xu, X. Wei et al., "Oxymatrine induces human pancreatic cancer PANC-1 cells apoptosis via regulating expression of Bcl-2 and IAP families, and releasing of cytochrome c," Journal of Experimental and Clinical Cancer Research, vol. 30, no. 1, article 66, 2011.

[122] S. T. Chou, H. Y. Peng, C. T. Chang et al., "Zanthoxylum ailanthoides Sieb and Zucc. extract inhibits growth and induces cell death through G2/M-phase arrest and activation of apoptotic signals in colo 205 human colon adenocarcinoma cells," Anticancer Research, vol. 31, no. 5, pp. 1667-1676, 2011.

[123] H. Xu, Y. Huang, Y. Wu et al., "Pharicin A, a novel natural ent-kaurene diterpenoid, induces mitotic arrest and mitotic catastrophe of cancer cells by interfering with BubR1 function," Cell Cycle, vol. 9, no. 14, pp. 2897-2907, 2010. 
[124] J. K. Shen, H. P. Du, M. Yang, Y. G. Wang, and J. Jin, "Casticin induces leukemic cell death through apoptosis and mitotic catastrophe," Annals of Hematology, vol. 88, no. 8, pp. 743-752, 2009.

[125] D. Hu, Q. Liu, H. Cui, H. Wang, D. Han, and H. Xu, "Effects of amino acids from selenium-rich silkworm pupas on human hepatoma cells," Life Sciences, vol. 77, no. 17, pp. 2098-2110, 2005.

[126] B. Tan, J. F. Huang, Q. Wei, H. Zhang, and R. Z. Ni, "Antihepatoma effect of arsenic trioxide on experimental liver cancer induced by 2-acetamidofluorene in rats," World Journal of Gastroenterology, vol. 11, no. 38, pp. 5938-5943, 2005.

[127] E. Calviño, M. C. Estañ, G. P. Simón et al., "Increased apoptotic efficacy of lonidamine plus arsenic trioxide combination in human leukemia cells. Reactive oxygen species generation and defensive protein kinase (MEK/ERK, Akt/mTOR) modulation," Biochemical Pharmacology, vol. 82, no. 11, pp. 1619-1629, 2011.

[128] C. W. Chien, J. H. Yao, S. Y. Chang, P. C. Lee, and T. C. Lee, "Enhanced suppression of tumor growth by concomitant treatment of human lung cancer cells with suberoylanilide hydroxamic acid and arsenic trioxide," Toxicology and Applied Pharmacology, vol. 257, no. 1, pp. 59-66, 2011.

[129] H. W. Chiu, Y. A. Chen, S. Y. Ho, and Y. J. Wang, "Arsenic trioxide enhances the radiation sensitivity of androgen-dependent and -independent human prostate cancer cells," PLOS ONE, vol. 7, no. 2, Article ID e31579, 2012.

[130] R. C. Sun, P. G. Board, and A. C. Blackburn, "Targeting metabolism with arsenic trioxide and dichloroacetate in breast cancer cells," Molecular Cancer, vol. 10, article 142, 2011.

[131] C. Kuo, T. Wu, L. Chen et al., "Combination of arsenic trioxide and BCNU synergistically triggers redox-mediated autophagic cell death in human solid tumors," Free Radical Biology and Medicine, vol. 51, no. 12, pp. 2195-2209, 2011.

[132] K. Cain, "Chemical-induced apoptosis: formation of the Apaf-1 apoptosome," Drug Metabolism Reviews, vol. 35, no. 4, pp. 337$363,2003$.

[133] M. Castedo, J.-L. Perfettini, T. Roumier, K. Andreau, R. Medema, and G. Kroemer, "Cell death by mitotic catastrophe: a molecular definition," Oncogene, vol. 23, no. 16, pp. 2825-2837, 2004.

[134] X. Su, X. Wang, F. Zhang et al., "Ursolic acid inhibits proliferation and induces apoptosis of cancer cells in vitro and in vivo," Journal of Biomedicine and Biotechnology, vol. 2011, Article ID 419343, 8 pages, 2011.

[135] P. Manikandan, R. S. Murugan, R. V. Priyadarsini, G. Vinothini, and S. Nagini, "Eugenol induces apoptosis and inhibits invasion and angiogenesis in a rat model of gastric carcinogenesis induced by MNNG," Life Sciences, vol. 86, no. 25-26, pp. 936941, 2010.

[136] A. T. K. Singh, M. Ghosh, T. M. Forte, R. O. Ryan, and L. I. Gordon, "Curcumin nanodisk-induced apoptosis in mantle cell lymphoma," Leukemia and Lymphoma, vol. 52, no. 8, pp. 15371543, 2011.

[137] F. Ye, L. Xui, J. Yi, W. Zhang, and D. Y. Zhang, "Anticancer activity of Scutellaria baicalensis and its potential mechanism," The Journal of Alternative and Complementary Medicine, vol. 8, no. 5, pp. 567-572, 2002.

[138] P. S. Patel, N. Joshee, A. M. Rimando, and P. Parajuli, "Anticancer scopes and associated mechanisms of Scutellaria extract and flavonoid wogonin," Current Cancer Therapy Reviews, vol. 9, no. 1, pp. 34-42, 2013.

[139] S. Ikemoto, K. Sugimura, N. Yoshida et al., "Antitumor effects of Scutellariae radix and its components baicalein, baicalin, and wogonin on bladder cancer cell lines," Urology, vol. 55, no. 6, pp. 951-955, 2000.

[140] B. Y. Khoo, S. L. Chua, and P. Balaram, "Apoptotic effects of chrysin in human cancer cell lines," International Journal of Molecular Sciences, vol. 11, no. 5, pp. 2188-2199, 2010.

[141] Y.-X. Wu and X. Fang, "Apigenin, chrysin, and luteolin selectively inhibit chymotrypsin-like and trypsin-like proteasome catalytic activities in tumor cells," Planta Medica, vol. 76, no. 2, pp. 128-132, 2010.

[142] R. Kachadourian, H. M. Leitner, and B. J. Day, "Selected flavonoids potentiate the toxicity of cisplatin in human lung adenocarcinoma cells: a role for glutathione depletion," International Journal of Oncology, vol. 31, no. 1, pp. 161-168, 2007.

[143] H. M. Brechbuhl, R. Kachadourian, E. Min, D. Chan, and B. J. Day, "Chrysin enhances doxorubicin-induced cytotoxicity in human lung epithelial cancer cell lines: the role of glutathione," Toxicology and Applied Pharmacology, vol. 258, no. 1, pp. 1-9, 2012.

[144] R. Kachadourian and B. J. Day, "Flavonoid-induced glutathione depletion: potential implications for cancer treatment," Free Radical Biology and Medicine, vol. 41, no. 1, pp. 65-76, 2006.

[145] L. Galluzzi and G. Kroemer, "Necroptosis: a specialized pathway of programmed necrosis," Cell, vol. 135, no. 7, pp. 1161-1163, 2008.

[146] Z. Ma, K. Otsuyama, S. Liu et al., "Baicalein, a component of Scutellaria radix from Huang-Lian-Jie-Du-Tang (HLJDT), leads to suppression of proliferation and induction of apoptosis in human myeloma cells," Blood, vol. 105, no. 8, pp. 3312-3318, 2005.

[147] Y. L. Hsu, P. L. Kuo, T. F. Tzeng et al., "Huang-lian-jie-du-tang, a traditional Chinese medicine prescription, induces cell-cycle arrest and apoptosis in human liver cancer cells in vitro and in vivo," Journal of Gastroenterology and Hepatology, vol. 23, no. 7, part 2, pp. e290-e299, 2008.

[148] M. B. Antonoff, R. Chugh, S. J. Skube et al., "Role of Hsp-70 in triptolide-mediated cell death of neuroblastoma," Journal of Surgical Research, vol. 163, no. 1, pp. 72-78, 2010.

[149] M. J. Kim, T. H. Lee, S. H. Kim, Y. Choi, J. Heo, and Y. Kim, "Triptolide inactivates Akt and induces caspase-dependent death in cervical cancer cells via the mitochondrial pathway," International Journal of Oncology, vol. 37, no. 5, pp. 1177-1185, 2010.

[150] L. Lu, J. Kanwar, S. Schmitt et al., "Inhibition of tumor cellular proteasome activity by triptolide extracted from the Chinese medicinal plant "thunder god vine"', Anticancer Research, vol. 31, no. 1, pp. 1-10, 2011.

[151] F. Zhao, Y. Chen, L. Zeng et al., "Effects of triptolide on RIZ1 expression, proliferation, and apoptosis in multiple myeloma U266 cells," Acta Pharmacologica Sinica, vol. 31, no. 6, pp. 733740, 2010.

[152] G. S. Zhou, Z. Hu, H. T. Fang et al., "Biologic activity of triptolide in $\mathrm{t}(8 ; 21)$ acute myeloid leukemia cells," Leukemia Research, vol. 35, no. 2, pp. 214-218, 2011.

[153] J. M. Tarr, N. Ding, K. Kaul, A. Antonell, L. A. Pérez-Jurado, and R. Chibber, "Cellular crosstalk between TNF- $\alpha$, NADPH oxidase, PKC $\beta 2$, and C2GNT in human leukocytes," Cellular Signalling, vol. 24, no. 4, pp. 873-878, 2012.

[154] N. Mizushima, A. Yamamoto, M. Matsui, T. Yoshimori, and Y. Ohsumi, "In vivo analysis of autophagy in response to nutrient starvation using transgenic mice expressing a fluorescent autophagosome marker," Molecular Biology of the Cell, vol. 15, no. 3, pp. 1101-1111, 2004. 
[155] S. Sperandio, K. Poksay, I. de Belle et al., "Paraptosis: mediation by MAP kinases and inhibition by AIP-1/Alix," Cell Death and Differentiation, vol. 11, no. 10, pp. 1066-1075, 2004.

[156] Y. Wang, X. Li, L. Wang et al., "An alternative form of paraptosislike cell death, triggered by TAJ/TROY and enhanced by PDCD5 overexpression," Journal of Cell Science, vol. 117, part 8, pp. 1525-1532, 2004.

[157] B. Hu, H. An, K. Shen et al., "Modified Yi Guan Jian, a Chinese herbal formula, induces anoikis in Bel-7402 human hepatocarcinoma cells in vitro," Oncology Reports, vol. 26, no. 6, pp. 1465-1470, 2011.

[158] J. Tang, Y. Feng, S. Tsao, N. Wang, R. Curtain, and Y. Wang, "Berberine and Coptidis rhizoma as novel antineoplastic agents: a review of traditional use and biomedical investigations," Journal of Ethnopharmacology, vol. 126, no. 1, pp. 5-17, 2009. 


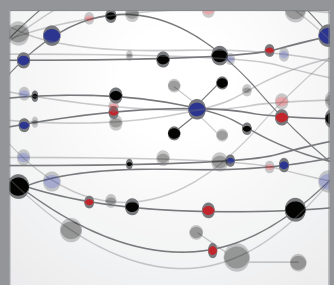

The Scientific World Journal
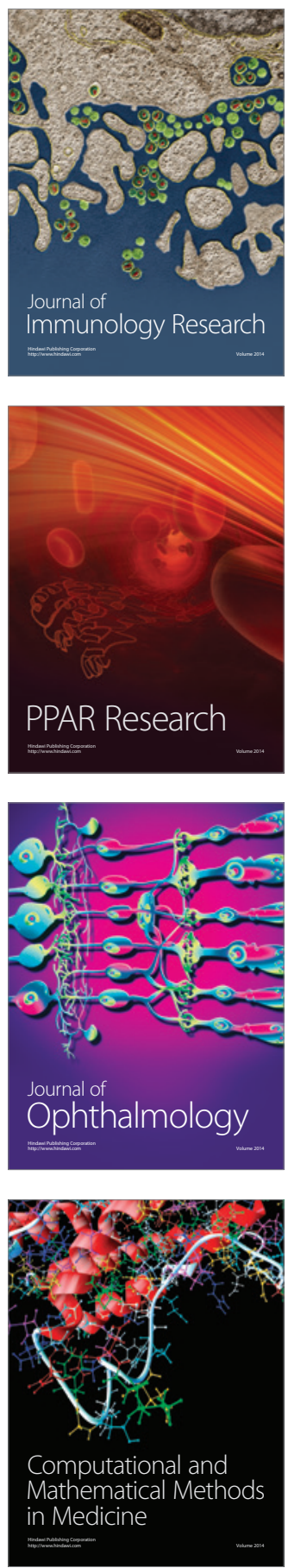

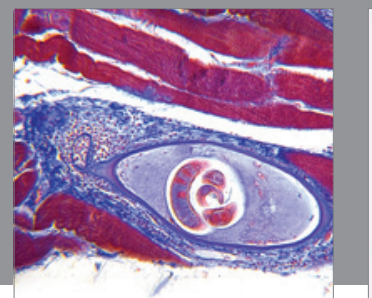

Gastroenterology

Research and Practice
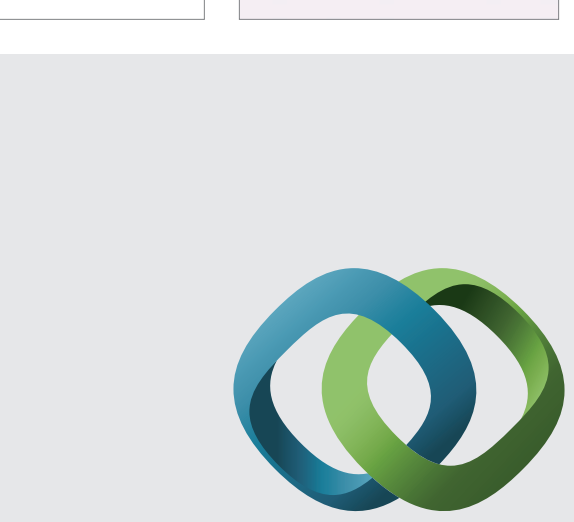

\section{Hindawi}

Submit your manuscripts at

http://www.hindawi.com
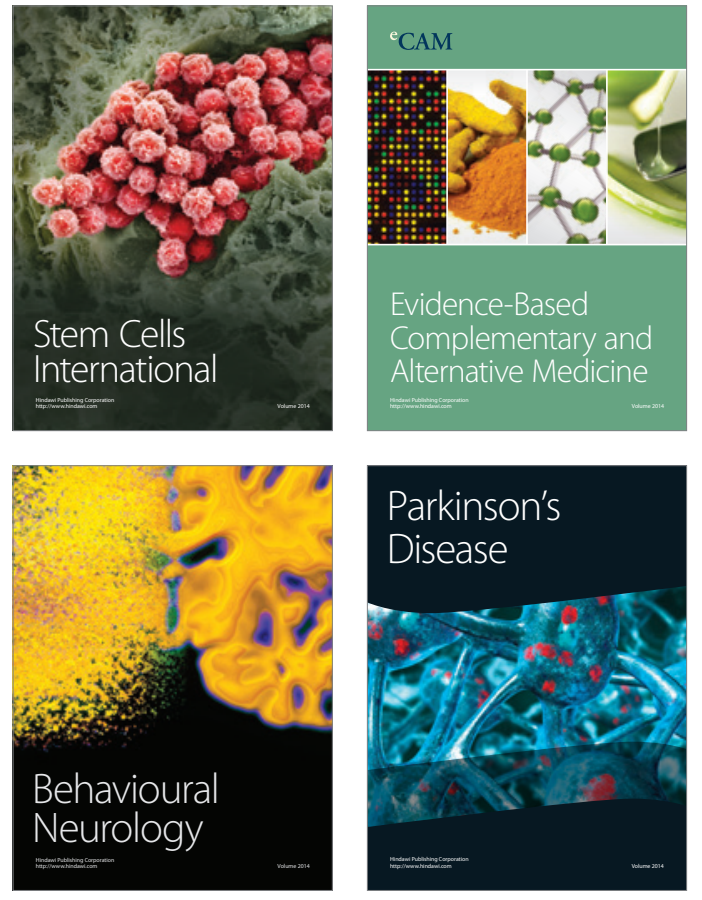
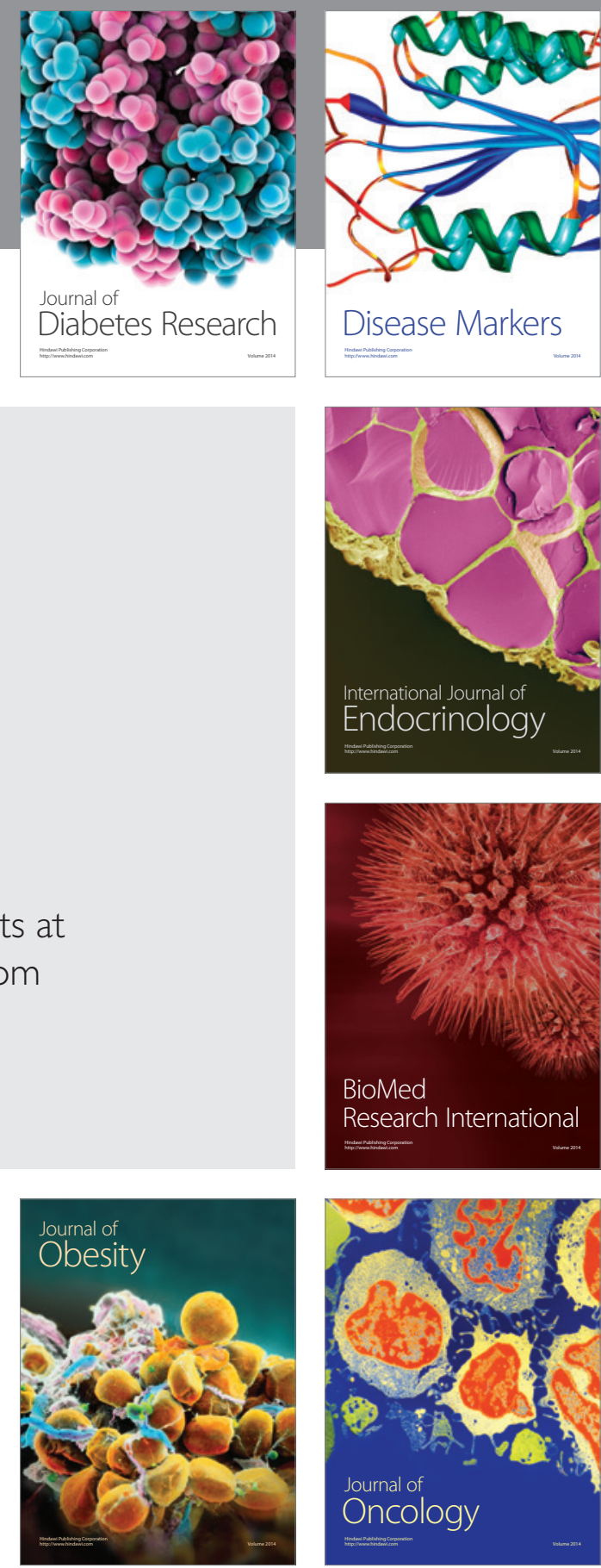

Disease Markers
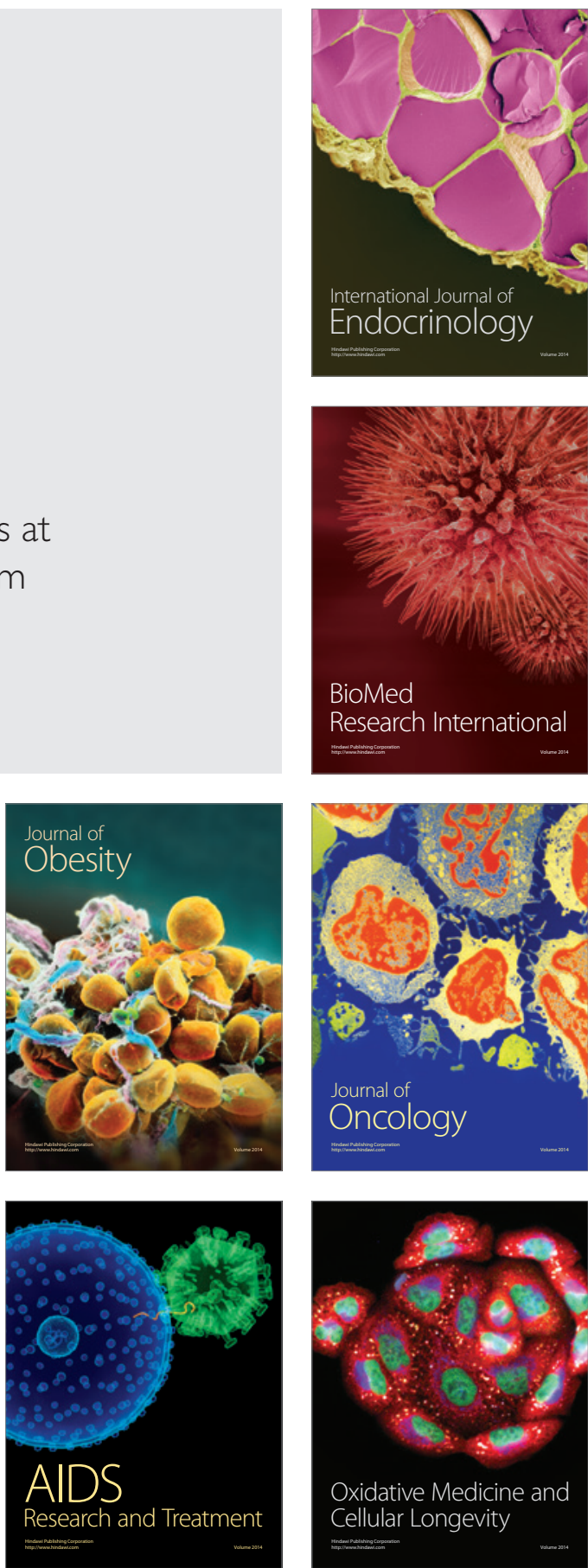